\title{
Nocardiopsis litoralis sp. nov., a halophilic marine actinomycete isolated from a sea anemone
}

\author{
Correspondence \\ Wen-Jun Li \\ wjli@ynu.edu.cn \\ Yi-Guang Chen \\ mchenjsu@yahoo.com.cn
}

\author{
Yi-Guang Chen, ${ }^{1,2}$ Yong-Xia Wang, ${ }^{2}$ Yu-Oin Zhang, ${ }^{3}$ Shu-Kun Tang, ${ }^{2}$ \\ Zhi-Xiong Liu, ${ }^{1}$ Huai-Dong Xiao, ${ }^{1}$ Li-Hua Xu, ${ }^{2}$ Xiao-Long Cui ${ }^{2}$ \\ and Wen-Jun $\mathrm{Li}^{2,4}$
}
${ }^{1}$ College of Biology and Environmental Sciences, College of Chemistry and Chemical Engineering, Jishou University, Jishou 416000, PR China
${ }^{2}$ The Key Laboratory for Microbial Resources of the Ministry of Education, PR China, and Laboratory for Conservation and Utilization of Bio-Resources, Yunnan Institute of Microbiology, Yunnan University, Kunming 650091, PR China
${ }^{3}$ Institute of Medicinal Biotechnology, Chinese Academy of Medical Sciences and Peking Union Medical College, Beijing 100050, PR China
${ }^{4}$ Guangdong Key Laboratory of Marine Materia Medica, South China Sea Institute of Oceanology, Chinese Academy of Sciences, Guangzhou 510301, PR China

\begin{abstract}
A Gram-positive, moderately halophilic, alkalitolerant, filamentous, aerobic actinomycete, designated strain JSM $073097^{\top}$, was isolated from a sea anemone collected from a tidal flat in the South China Sea. Phylogenetic analyses based on 16S rRNA gene sequences indicated that the new isolate was a member of the genus Nocardiopsis and was most closely related to Nocardiopsis kunsanensis $\mathrm{HA}-9^{\top}$, Nocardiopsis xinjiangensis $\mathrm{YIM} 90004^{\top}$ and Nocardiopsis salina YIM $90010^{\top}$ (99.6, 98.5 and $98.1 \%$ similarity, respectively). Phenotypic characteristics and chemotaxonomic data also indicated that strain JSM $073097^{\top}$ was a member of the genus Nocardiopsis. The strain grew well on most of the media tested, producing white to yellow-white substrate mycelium and white aerial mycelium and straight to flexuous hyphae. The substrate mycelium was well developed and fragmented with age; the aerial mycelium produced long, straight to flexuous spore chains with non-motile, smooth-surfaced, rod-shaped spores. The strain grew in the presence of $1-15 \%(\mathrm{w} / \mathrm{v})$ total salts and at $\mathrm{pH} 6.0-10.5$ and $20-35{ }^{\circ} \mathrm{C}$; optimum growth occurred in the presence of $5-7 \%(\mathrm{w} / \mathrm{v})$ total salts and at $\mathrm{pH} 8.5$ and $25{ }^{\circ} \mathrm{C}$. Whole-cell hydrolysates of strain JSM $073097^{\top}$ contained meso-diaminopimelic acid and no diagnostic sugars. The predominant menaquinones were $\mathrm{MK}-10\left(\mathrm{H}_{4}\right), \mathrm{MK}-10\left(\mathrm{H}_{6}\right)$ and $\mathrm{MK}-10\left(\mathrm{H}_{8}\right)$. The major cellular fatty acids were iso- $\mathrm{C}_{15: 0}$, iso- $\mathrm{C}_{16: 0}$, anteiso- $\mathrm{C}_{16: 0}$ and 10-methyl $\mathrm{C}_{18: 0}$. Polar lipids comprised diphosphatidylglycerol, phosphatidylcholine and phosphatidylglycerol. The DNA G+C content of strain JSM $073097^{\top}$ was 70.4 mol\%. The combination of phylogenetic analysis, DNADNA relatedness data, phenotypic characteristics and chemotaxonomic data supported the suggestion that strain JSM $073097^{\top}$ represents a novel species of the genus Nocardiopsis, for which the name Nocardiopsis litoralis sp. nov. is proposed. The type strain is JSM $073097^{\top}$ $\left(=\mathrm{DSM} 45168^{\mathrm{T}}=\right.$ KCTC $\left.19473^{\mathrm{T}}\right)$.
\end{abstract}

The genus Nocardiopsis was first described by Meyer (1976) and, at the time or writing, comprises 28 recognized species

The GenBank/EMBL/DDBJ accession number for the $16 \mathrm{~S}$ rRNA gene sequence of strain JSM $073097^{\top}$ is EU583726.

A scanning electron micrograph of cells of strain JSM $073097^{\top}$ and maximum-parsimony and maximum-likelihood phylogenetic trees showing the position of strain JSM $073097^{\top}$ among members of the genus Nocardiopsis based on 16S rRNA gene sequences are available with the online version of this paper.
(Meyer, 1976; Grund \& Kroppenstedt, 1990; Yassin et al., 1993, 1997; Al-Tai \& Ruan, 1994; Chun et al., 2000; Evtushenko et al., 2000; Peltola et al., 2001; Al-Zarban et al., 2002; Kämpfer et al., 2002; Schippers et al., 2002; Li et al., 2003, 2004, 2006; Hozzein et al., 2004; Sabry et al., 2004; Chen et al., 2008; Hozzein \& Goodfellow, 2008; Yang et al., 2008; Zhang et al., 2008). During an investigation of the diversity of the microbial population of invertebrates inhabiting the South China Sea (Chen et al., 2009a, b; Xiao et al., 2009), a moderately halophilic, alkalitolerant, 
filamentous, Gram-positive strain, designated JSM $073097^{\mathrm{T}}$, was isolated from a sea anemone collected from a tidal flat near Naozhou Island, southern China. Based on the results of the present taxonomic study, this strain is considered to represent a novel species of the genus Nocardiopsis.

Strain JSM $073097^{\mathrm{T}}$ was isolated from homogenates of a sea anemone by plating $1: 10$ serial dilutions of the sample on marine agar 2216 (MA; Difco) supplemented with $10 \%$ $(\mathrm{w} / \mathrm{v}) \mathrm{NaCl}$ and cultivating at $25{ }^{\circ} \mathrm{C}$ for 2 weeks. After primary isolation and purification, the isolate was preserved both on slants of MA supplemented with $3 \%(\mathrm{w} / \mathrm{v})$ $\mathrm{NaCl}$ (containing approximately $5 \% \mathrm{NaCl}$ and $6.4 \%$ total salts, $\mathrm{pH}$ 8.5; hereafter referred to as MA3) at $4{ }^{\circ} \mathrm{C}$ and in marine broth 2216 (MB; Difco) supplemented with $20 \%$ $(\mathrm{v} / \mathrm{v})$ glycerol at $-80{ }^{\circ} \mathrm{C}$. Nocardiopsis kunsanensis DSM $44524^{\mathrm{T}}$, Nocardiopsis xinjiangensis YIM $90004^{\mathrm{T}}$ and Nocardiopsis salina YIM $90010^{\mathrm{T}}$ were obtained from the DSMZ (Deutsche Sammlung von Mikroorganismen und Zellkulturen, Braunschweig, Germany) and the YIM (Yunnan Institute of Microbiology, Kunming, China). Morphological characteristics were observed by using light microscopy (BH 2; Olympus) and scanning electron microscopy (JSM5600LV; JEOL) after 2 and 4 weeks growth on MA3. Cultural characteristics were determined after 2-4 weeks by using the methods applied in the International Streptomyces Project (Shirling \& Gottlieb, 1966). The colours of both substrate and aerial mycelia and any soluble pigments produced were determined by comparison with chips from the colour charts of the Inter-Society Colour Council - National Bureau of Standards (Kelly, 1964). Growth was tested at various temperatures $\left(5-45{ }^{\circ} \mathrm{C}\right.$, at increments of $\left.5{ }^{\circ} \mathrm{C}\right)$ and $\mathrm{pH}$ (5.0-11.0, at $\mathrm{pH}$ increments of 0.5$)$ in $\mathrm{MB}$ supplemented with $3 \%(\mathrm{w} / \mathrm{v}) \mathrm{NaCl}$ and on MA3. Turbidity was monitored at $610 \mathrm{~nm}$ after the $\mathrm{MB}$ tubes had been incubated for 5 days in a reciprocal water-bath shaker. Growth at different total salt contents $(0,0.1$ and $0.5 \%$, $\mathrm{w} / \mathrm{v}$, and $1-20 \%$, w/v, at increments of $1 \%$ ) was determined on MA prepared according to the formula of Atlas (1993). The concentration of total salts contained in MA was changed (proportions maintained) as an integer in the salt-response experiment. Growth under anaerobic conditions and catalase and oxidase activities were detected as described previously (Chen et al., 2007). The media and procedures used to determine physiological and biochemical features, as well as utilization of carbon and nitrogen sources, were those described by Shirling \& Gottlieb (1966) and Kroppenstedt \& Evtushenko (2006). Unless indicated otherwise, all tests were carried out with $6 \%(\mathrm{w} / \mathrm{v}) \mathrm{NaCl}$ at $\mathrm{pH} 8.5$ with incubation at $25{ }^{\circ} \mathrm{C}$.

Strain JSM $073097^{\mathrm{T}}$ showed macroscopic and microscopic characteristics typical of most species of the genus Nocardiopsis (Meyer, 1976, 1994; Kroppenstedt \& Evtushenko, 2006). The novel strain was Gram-positive, obligately aerobic and catalase-positive. It formed circular colonies that had white mycelia on MA3. Good growth was also observed on yeast extract-malt extract, oatmeal, peptone-yeast extract-iron, Czapek's, nutrient and potato extract agar media supplemented with $6 \%(\mathrm{w} / \mathrm{v}) \mathrm{NaCl}$, but poor growth occurred on inorganic salts-starch and glycerol-asparagine agar media supplemented with $6 \%$ (w/v) $\mathrm{NaCl}$. Substrate mycelia were well developed and fragmented with age. Aerial mycelia produced long, straight to flexuous spore chains with non-motile, smooth-surfaced, rod-shaped spores (see Supplementary Fig. S1 in IJSEM Online). No diffusible pigments were produced on any of the media tested. Strain JSM $073097^{\mathrm{T}}$ was able to grow at $20-35{ }^{\circ} \mathrm{C}$ (optimum $25{ }^{\circ} \mathrm{C}$ ) and at $\mathrm{pH}$ 6.0-10.5 (optimum $\mathrm{pH} 8.5$ ) in the presence of $1-15 \%$ (w/v) total salts (optimum 5-7\%). The results of other phenotypic tests are summarized in the species description below and in Table 1.

DNA was isolated according to the method of Hopwood et al. (1985) and the $\mathrm{G}+\mathrm{C}$ content was determined by using the HPLC method (Mesbah et al., 1989). The 16S rRNA gene was amplified and sequenced as described by Cui et al. (2001). The resulting 16S rRNA gene sequence was compared with sequences obtained from public databases (GenBank/EMBL/DDBJ) to find the most closely related species. Multiple alignments with sequences of the most closely related strains were carried out by using CLUSTAL_X (Thompson et al., 1997). Distances were calculated by using distance options according to Kimura's two-parameter model (Kimura, 1980). A neighbour-joining (Saitou \& Nei, 1987) tree was constructed by using the software package MEGA version 4.1 (Tamura et al., 2007). Maximum-likelihood (Felsenstein, 1981) and maximum-parsimony (Kluge \& Farris, 1969) trees were generated by using the treeing algorithms contained in the PHYLIP package (Felsenstein, 2002). Confidence values for the branches of phylogenetic trees were determined by using bootstrap analyses (Felsenstein, 1985) based on 1000 resamplings. DNA-DNA hybridization experiments were carried out by using photobiotin-labelled probes in microplate wells as described by Ezaki et al. (1989).

The DNA G $+\mathrm{C}$ content of strain JSM $073097^{\mathrm{T}}$ was $70.4 \mathrm{~mol} \%$. An almost-complete $16 \mathrm{~S}$ rRNA gene sequence (1404 bp) of this organism was determined. Phylogenetic analyses based on 16S rRNA gene sequences revealed that strain JSM $073097^{\mathrm{T}}$ belonged to the genus Nocardiopsis, and was most closely related to the type strain of $N$. kunsanensis (99.6\% similarity; Chun et al., 2000), followed by those of $N$. xinjiangensis ( $98.5 \%$; Li et al., 2003) and $N$. salina (98.1\%; Li et al., 2004). The four strains formed a robust lineage supported by a significant bootstrap resampling value $(99 \%)$ in the neighbour-joining tree (Fig. 1). The topology was similar to those of the phylogenetic trees constructed by using the maximumlikelihood and maximum-parsimony methods (see Supplementary Fig. S2). Levels of DNA-DNA relatedness between strain JSM $073097^{\mathrm{T}}$ and the type strains of $N$. kunsanensis, $N$. xinjiangensis and $N$. salina were $30.7 \pm 2.8$, $20.6 \pm 2.3$ and $22.1 \pm 2.9 \%$ (mean \pm SD of 3 determinations), 
Table 1. Differential characteristics between strain JSM $073097^{\top}$ and phylogenetically related species of the genus Nocardiopsis

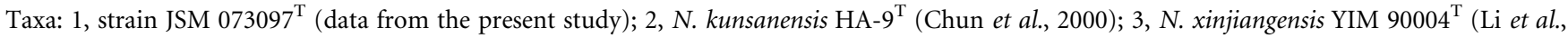
2003); 4, N. salina YIM $90010^{\mathrm{T}}$ (Li et al., 2004, 2006). +, Positive; -, negative; w, weak reaction; ND, no data available.

\begin{tabular}{|c|c|c|c|c|}
\hline Characteristic & 1 & 2 & 3 & 4 \\
\hline Fragmentation of substrate mycelia & + & - & + & + \\
\hline $\mathrm{NaCl}$ range (optimum) $(\% ; \mathrm{w} / \mathrm{v})^{*}$ & $1-15(5-7)$ & $3-20(10)$ & $3-20(10) \dagger$ & $3-20(10)$ \\
\hline Temperature range (optimum) $\left({ }^{\circ} \mathrm{C}\right)$ & $20-35(25)$ & $20-50(37) \dagger$ & $20-40(28) \dagger$ & $20-40(28)$ \\
\hline $\mathrm{pH}$ range (optimum) & $6.0-10.5(8.5)$ & $7.0-11.0(9.0) \dagger$ & $6.0-10.0(7.2) \dagger$ & $6.0-9.0(7.2)$ \\
\hline Urease activity & - & + & + & - \\
\hline Melanin production & - & - & + & - \\
\hline Nitrate reduction & - & - & - & + \\
\hline \multicolumn{5}{|l|}{ Hydrolysis of: } \\
\hline Casein & - & + & $\mathrm{ND}$ & $\mathrm{ND}$ \\
\hline Gelatin & + & - & + & $\mathrm{w}$ \\
\hline Starch & - & + & - & - \\
\hline \multicolumn{5}{|l|}{ Utilization of: } \\
\hline D-Cellobiose & - & - & + & - \\
\hline D-Fructose & - & $+\dagger$ & $+\dagger$ & + \\
\hline D-Galactose & - & - & + & - \\
\hline D-Glucose & + & + & - & - \\
\hline L-Proline & - & - & + & + \\
\hline Raffinose & - & - & - & + \\
\hline L-Serine & - & - & + & + \\
\hline D-Xylose & + & $-\dagger$ & - & - \\
\hline Diagnostic sugars & None & None & Xylose, arabinose, galactose & None \\
\hline Major phospholipids $\ddagger$ & DPG, PC, PG & DPG, PC, PG & PG, PI & $\begin{array}{c}\text { DPG, PC, PE, PG, PI, } \\
\text { PME }\end{array}$ \\
\hline Major fatty acids & $\begin{array}{c}\text { iso- } \mathrm{C}_{15: 0}, \text { iso- } \mathrm{C}_{16: 0}, \\
\text { anteiso- } \mathrm{C}_{16: 0} \\
\text { 10-methyl } \mathrm{C}_{18: 0}\end{array}$ & $\begin{array}{l}\text { iso- } \mathrm{C}_{15: 0} \\
\text { anteiso- } \mathrm{C}_{16: 0} \\
\text { 10-methyl } \mathrm{C}_{18: 0}\end{array}$ & $\begin{array}{l}\text { iso- } \mathrm{C}_{14: 0} \text {, anteiso- } \mathrm{C}_{15: 0} \text {, } \\
\text { iso- } \mathrm{C}_{16: 0} \text {, anteiso- } \mathrm{C}_{16: 0} \\
\mathrm{C}_{18: 0}, 10 \text {-methyl } \mathrm{C}_{18: 0}\end{array}$ & $\begin{array}{c}\text { iso- } \mathrm{C}_{16: 0}, \mathrm{C}_{18: 1} \omega 9 c \\
10 \text {-methyl } \mathrm{C}_{18: 0}\end{array}$ \\
\hline Major menaquinone(s) & MK-10 $\left(\mathrm{H}_{4}, \mathrm{H}_{6}, \mathrm{H}_{8}\right)$ & $\mathrm{MK}-10\left(\mathrm{H}_{8}\right)$ & MK-10 $\left(\mathrm{H}_{2}, \mathrm{H}_{4}\right)$ & MK-9 $\left(\mathrm{H}_{8}\right)$, MK-10 $\left(\mathrm{H}_{8}\right)$ \\
\hline DNA G $+C$ content $(\mathrm{mol} \%)$ & 70.4 & 71 & 74.3 & 73.1 \\
\hline
\end{tabular}

${ }^{\star}$ Data for strain JSM $073097^{\mathrm{T}}$ were for total salts.

$\dagger$ Data obtained from Li et al. (2004).

¥DPG, diphosphatidylglycerol; PC, phosphatidylcholine; PE, phosphatidylethanolamine; PG, phosphatidylglycerol; PI, phosphatidylinositol; PME, phosphatidylmethylethanolamine.

respectively. These values are far below the threshold of $70 \%$ recommended by Wayne et al. (1987) for assignment of strains to the same species. The other closest phylogenetic neighbours of strain JSM $073097^{\mathrm{T}}$ (showing 16S rRNA gene sequence similarity $>97 \%$ ) were the type strains of Nocardiopsis aegyptia (97.7\%), Nocardiopsis lucentensis (97.5\%), Nocardiopsis alba (97.4\%), Nocardiopsis dassonvillei subsp. dassonvillei (97.4\%) and Nocardiopsis dassonvillei subsp. albirubida (97.2\%). These levels of sequence similarity are lower than those found for some other individual pairs of recognized Nocardiopsis species, as discussed previously (Al-Zarban et al., 2002; Schippers et al., 2002; Hozzein et al., 2004; Sabry et al., 2004; Yang et al., 2008). Furthermore, Stackebrandt \& Ebers (2006) suggested an increase from 97 to $98.7-99 \%$ in the $16 \mathrm{~S}$ rRNA gene sequence similarity threshold used for the delineation of separate species, provided that these data are supported by clear phenotypic differences. On this basis, together with
DNA-DNA hybridization data, the present phylogenetic analyses strongly suggested that strain JSM $073097^{\mathrm{T}}$ represents a previously unknown species of the genus Nocardiopsis.

Biomass for chemical studies was obtained from cultures grown in $\mathrm{MB}(\mathrm{pH} 8.5)$ supplemented with $3 \%(\mathrm{w} / \mathrm{v}) \mathrm{NaCl}$ on a rotary shaker (about 200 r.p.m.) at $25{ }^{\circ} \mathrm{C}$ for 3 days. Cells were harvested by centrifugation and were washed twice with distilled water. Amino acids and sugars of whole-cell hydrolysates were analysed as described by Staneck \& Roberts (1974). Polar lipids were extracted, examined by using two-dimensional TLC and identified by using standard procedures (Minnikin et al., 1984). Menaquinones were isolated by using the methods of Minnikin et al. (1984) and were then separated by HPLC (Kroppenstedt, 1982, 1985). Fatty acids were determined as described by Sasser (1990) by using the Microbial 


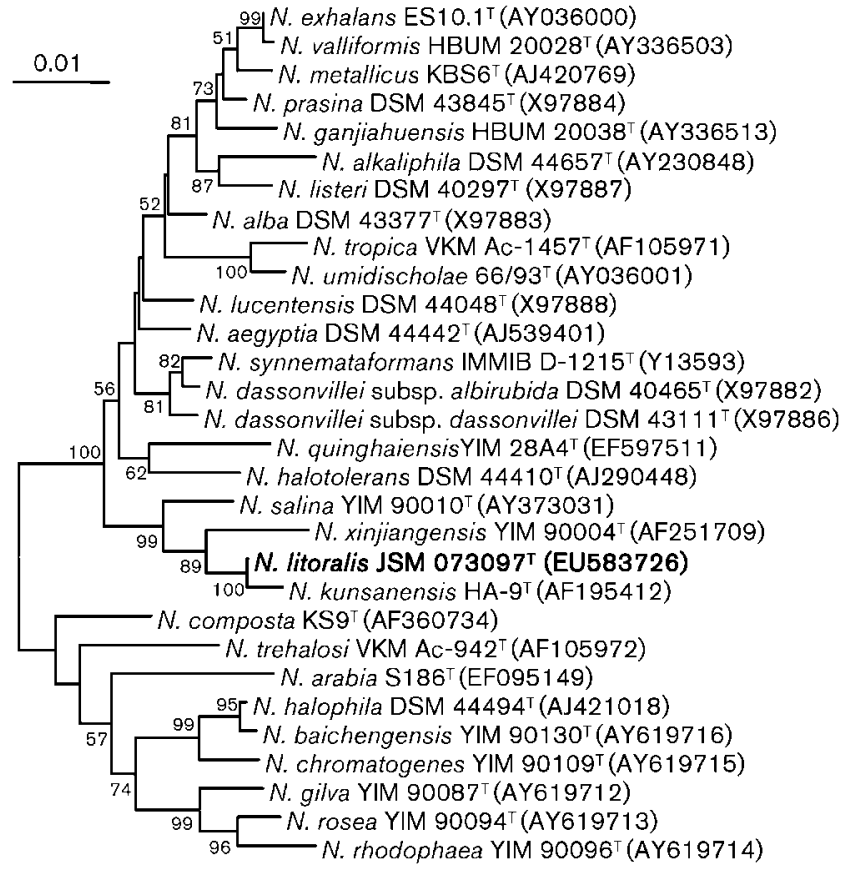

Fig. 1. Phylogenetic tree based on $16 \mathrm{~S}$ rRNA gene sequence analysis and constructed by using the neighbour-joining method showing the position of strain JSM $073097^{\top}$ among members of the genus Nocardiopsis. Numbers at nodes indicate bootstrap values $(>50 \%)$ based on a neighbour-joining analysis of 1000 resampled datasets. Bar, 1 substitution per $100 \mathrm{nt}$.

Identification System (MIDI; Microbial ID). Chemotaxonomic data for strain JSM $073097^{\mathrm{T}}$ were consistent with its assignment to the genus Nocardiopsis (Meyer, 1976, 1994; Kroppenstedt \& Evtushenko, 2006). Whole-cell hydrolysates contained meso-diaminopimelic acid as the diagnostic diamino acid and no diagnostic sugars. Polar lipids of the novel strain comprised diphosphatidylglycerol, phosphatidylcholine and phosphatidylglycerol. The predominant menaquinones were MK$10\left(\mathrm{H}_{4}\right)(32.3 \%)$, MK-10 $\left(\mathrm{H}_{6}\right)(36.8 \%)$ and $\mathrm{MK}-10\left(\mathrm{H}_{8}\right)$ (16.3\%), with MK-9( $\left.\mathrm{H}_{6}\right)(5.8 \%)$, MK-9 $\left(\mathrm{H}_{8}\right)(2.7 \%)$ and MK-10 $\left(\mathrm{H}_{2}\right)(5.2 \%)$ present as minor components. The fatty acid profile of strain JSM $073097^{\mathrm{T}}$ was similar to those of related Nocardiopsis species (Table 1). The major fatty acids of the novel strain were iso- $\mathrm{C}_{15: 0}(10.1 \%$ of the total), iso- $\mathrm{C}_{16: 0}(28.2 \%)$, anteiso- $\mathrm{C}_{16: 0}(11.8 \%)$ and 10-methyl $\mathrm{C}_{18: 0}(11.0 \%)$, with iso- $\mathrm{C}_{14: 0}(4.4 \%)$, anteiso$\mathrm{C}_{15: 0}(5.7 \%), \mathrm{C}_{16: 1} \omega 7 c$ alcohol $(2.4 \%), \mathrm{C}_{16: 0}(3.7 \%)$, iso- $\mathrm{C}_{17: 0}(1.1 \%)$, anteiso- $\mathrm{C}_{17: 0}(5.1 \%), \mathrm{C}_{17: 0}(1.2 \%), 10$ methyl $\mathrm{C}_{17: 0}(1.5 \%), \mathrm{C}_{18: 1} \omega 9 c(6.8 \%)$ and $\mathrm{C}_{18: 0}(4.5 \%)$ present as minor components; iso- $\mathrm{C}_{13: 0}, \mathrm{C}_{14: 0}, \mathrm{C}_{15: 0}$, $\mathrm{C}_{17: 1} \omega 8 c$ and iso- $\mathrm{C}_{18: 0}$ were detected at a level of $<1 \%$.

The results of phylogenetic analyses and of morphological and chemotaxonomic investigations supported the view that strain JSM $073097^{\mathrm{T}}$ should be assigned to the genus Nocardiopsis (Meyer, 1976, 1994; Kroppenstedt \&
Evtushenko, 2006). However, the comparatively low salinities $[1-15 \%(\mathrm{w} / \mathrm{v})$ total salts (optimum 5-7\%)] and temperatures $\left[20-35{ }^{\circ} \mathrm{C}\right.$ (optimum $25{ }^{\circ} \mathrm{C}$ )] for growth, as well as its ability to utilize D-xylose as sole carbon source, markedly differentiated the new isolate from the phylogenetically related Nocardiopsis species (Table 1). Strain JSM $073097^{\mathrm{T}}$ could also be distinguished from its closest phylogenetic neighbour, N. kunsanensis, based on other physiological, biochemical, nutritional and chemotaxonomic differences (see Table 1). Data from the present polyphasic taxonomic study, together with DNA-DNA hybridization data, indicated that strain JSM $073097^{\mathrm{T}}$ represents a novel species of the genus Nocardiopsis, for which we propose the name Nocardiopsis litoralis sp. nov.

\section{Description of Nocardiopsis litoralis sp. nov.}

Nocardiopsis litoralis (li.to.ra'lis. L. adj. litoralis of the shore).

Gram-positive, moderately halophilic, alkalitolerant, nonmotile, filamentous, aerobic actinomycete that forms white aerial mycelium and white to yellow-white substrate mycelium and straight to flexuous hyphae. Good growth occurs on most of the media tested. Diffusible pigments are not produced. Substrate hyphae are well developed and fragment with age. Long, straight to flexuous spore chains are borne on aerial hyphae, which fragment into elongated non-motile spores $(0.5-0.7 \times 1.5-1.8 \mu \mathrm{m}$ in size $)$ with smooth surfaces. Grows optimally at $25^{\circ} \mathrm{C}$ and $\mathrm{pH} 8.5$ and in the presence of $5-7 \%(\mathrm{w} / \mathrm{v})$ total salts. Growth is not observed in the absence of salts. Positive for catalase but negative for oxidase. Unable to reduce nitrate to nitrite. $\mathrm{H}_{2} \mathrm{~S}$ and melanin are not produced. Degrades adenine, gelatin, hypoxanthine, tyrosine and xanthine, but not aesculin, casein, cellulose, chitin, DNA, starch, Tweens (20, $40,60,80)$ or urea. The following compounds are utilized as sole source of carbon and energy or sole source of carbon, nitrogen and energy: D-glucose, sucrose, D-xylose and L-alanine. The following substances are not utilized: L-arabinose, cellobiose, dextrin, D-fructose, D-galactose, Dlactose, maltose, D-mannose, melezitose, melibiose, raffinose, L-rhamnose, D-ribose, D-salicin, trehalose, adonitol, D-arabitol, glycerol, myo-inositol, D-mannitol, D-sorbitol, acetate, citrate, gluconate, L-arginine, L-asparagine, L-glutamic acid, glycine, L-histidine, hydroxy-L-proline, L-isoleucine, L-leucine, L-methionine, L-phenylalanine, L-proline, L-serine, L-threonine and L-valine. Whole-cell hydrolysates contain meso-diaminopimelic acid and no diagnostic sugars. The predominant menaquinones are MK-10 $\left(\mathrm{H}_{4}\right)$, MK-10 $\left(\mathrm{H}_{6}\right)$ and MK-10 $\left(\mathrm{H}_{8}\right)$. The major cellular fatty acids are iso- $\mathrm{C}_{15: 0}$, iso- $\mathrm{C}_{16: 0}$, anteiso- $\mathrm{C}_{16: 0}$ and 10-methyl $\mathrm{C}_{18: 0}$. Polar lipids comprise diphosphatidylglycerol, phosphatidylcholine and phosphatidylglycerol.

The type strain, JSM $073097^{\mathrm{T}}\left(=\mathrm{DSM} 45168^{\mathrm{T}}=\right.$ KCTC $19473^{\mathrm{T}}$ ), was isolated from homogenates of a sea anemone collected from a tidal flat on Naozhou Island in the South China Sea, near Zhanjiang City, southern China. The DNA 
$\mathrm{G}+\mathrm{C}$ content of the type strain is $70.4 \mathrm{~mol} \%$ (HPLC method).

\section{Acknowledgements}

This work was supported by grants from the National Natural Science Foundation of China (NSFC) (30970007, 30860013), Jishou University (jsdxkyzz200811, JSS2009Z01), the Ministry of Science and Technology, PR China (2006BAE01A01-9, 863 Program, No. 2007AA021306, 973 Program, No. 2004CB719601) and the Yunnan Provincial Sciences and Technology Department (2005PY01-1, 2006C0006M, 2006C0004M). W.-J. L. was supported by Program for New Century Excellent Talents in University. We are grateful to $\mathrm{Mr}$ Yun Chen and Mr Ke Huang for their excellent technical assistance.

\section{References}

Al-Tai, A. M. \& Ruan, J. S. (1994). Nocardiopsis halophila sp. nov., a new halophilic actinomycete isolated from soil. Int J Syst Bacteriol 44, 474-478.

Al-Zarban, S. S., Abbas, I., Al-Musallam, A. A., Steiner, U., Stackebrandt, E. \& Kroppenstedt, R. M. (2002). Nocardiopsis halotolerans sp. nov., isolated from salt marsh soil in Kuwait. Int $J$ Syst Evol Microbiol 52, 525-529.

Atlas, R. M. (1993). Handbook of Microbiological Media. Edited by L. C. Parks. Boca Raton, FL: CRC Press.

Chen, Y.-G., Cui, X.-L., Pukall, R., Li, H.-M., Yang, Y.-L., Xu, L.-H., Wen, M.-L., Peng, Q. \& Jiang, C.-L. (2007). Salinicoccus kunmingensis sp. nov., a moderately halophilic bacterium isolated from a salt mine in Yunnan, south-west China. Int J Syst Evol Microbiol 57, 2327-2332.

Chen, Y.-G., Cui, X.-L., Kroppenstedt, R. M., Stackebrandt, E., Wen, M.-L., Xu, L.-H. \& Jiang, C.-L. (2008). Nocardiopsis quinghaiensis sp. nov., isolated from saline soil in China. Int J Syst Evol Microbiol 58, 699-705.

Chen, Y.-G., Zhang, Y.-Q., Shi, J.-X., Xiao, H.-D., Tang, S.-K., Liu, Z.-X., Huang, K., Cui, X.-L. \& Li, W.-J. (2009a). Jeotgalicoccus marinus sp. nov., a marine bacterium isolated from a sea urchin. Int J Syst Evol Microbiol 59, 1625-1629.

Chen, Y.-G., Zhang, Y.-Q., Xiao, H.-D., Liu, Z.-X., Yi, L.-B., Shi, J.-X., Zhi, X.-Y., Cui, X.-L. \& Li, W.-J. (2009b). Pontibacillus halophilus sp. nov., a moderately halophilic bacterium isolated from a sea urchin. Int J Syst Evol Microbiol 59, 1635-1639.

Chun, J., Bae, K. S., Moon, E. Y., Jung, S.-O., Lee, H. K. \& Kim, S.-J. (2000). Nocardiopsis kunsanensis sp. nov., a moderately halophilic actinomycete isolated from a saltern. Int J Syst Evol Microbiol 50, 1909-1913.

Cui, X.-L., Mao, P.-H., Zeng, M., Li, W.-J., Zhang, L.-P., Xu, L.-H. \& Jiang, C.-L. (2001). Streptomonospora salina gen. nov., sp. nov., a new member of the family Nocardiopsaceae. Int J Syst Evol Microbiol 51, 357-363.

Evtushenko, L. I., Taran, V. V., Akimov, V. N., Kroppenstedt, R. M., Tiedje, J. M. \& Stackebrandt, E. (2000). Nocardiopsis tropica sp. nov., Nocardiopsis trehalosi sp. nov., nom. rev. and Nocardiopsis dassonvillei subsp. albirubida subsp. nov., comb. nov. Int J Syst Evol Microbiol 50, 73-81.

Ezaki, T., Hashimoto, Y. \& Yabuuchi, E. (1989). Fluorometric deoxyribonucleic acid-deoxyribonucleic acid hybridization in microdilution wells as an alternative to membrane filter hybridization in which radioisotopes are used to determine genetic relatedness among bacterial strains. Int J Syst Bacteriol 39, 224-229.

Felsenstein, J. (1981). Evolutionary trees from DNA sequences: a maximum likelihood approach. J Mol Evol 17, 368-376.
Felsenstein, J. (1985). Confidence limits on phylogenies: an approach using the bootstrap. Evolution 39, 783-791.

Felsenstein, J. (2002). PHYLIP (phylogeny inference package), version 3.6a. Distributed by the author. Department of Genome Sciences, University of Washington, Seattle, USA.

Grund, E. \& Kroppenstedt, R. M. (1990). Chemotaxonomy and numerical taxonomy of the genus Nocardiopsis Meyer 1976. Int J Syst Bacteriol 40, 5-11.

Hopwood, D. A., Bibb, M. J., Chater, K. F., Kieser, T., Bruton, C. J., Kieser, H. M., Lydiate, D. J., Smith, C. P. \& Ward, J. M. (1985). Preparation of chromosomal, plasmid and phage DNA. In Genetic Manipulation of Streptomyces: a Laboratory Manual, pp. 79-80. Norwich, UK: John Innes Foundation.

Hozzein, W. N. \& Goodfellow, M. (2008). Nocardiopsis arabia sp. nov., a halotolerant actinomycete isolated from a sand-dune soil. Int J Syst Evol Microbiol 58, 2520-2524.

Hozzein, W. N., Li, W. J., Ali, M. I. A., Hammouda, O., Mousa, A. S., Xu, L.-H. \& Jiang, C.-L. (2004). Nocardiopsis alkaliphila sp. nov., a novel alkaliphilic actinomycete isolated from desert soil in Egypt. Int J Syst Evol Microbiol 54, 247-252.

Kämpfer, P., Busse, H.-J. \& Rainey, F. A. (2002). Nocardiopsis compostus sp. nov., from the atmosphere of a composting facility. Int $J$ Syst Evol Microbiol 52, 621-627.

Kelly, K. L. (1964). Inter-Society Color Council - National Bureau of Standards Color Name Charts Illustrated with Centroid Colors. Washington, DC: US Government Printing Office.

Kimura, M. (1980). A simple method for estimating evolutionary rates of base substitutions through comparative studies of nucleotide sequence. J Mol Evol 16, 111-120.

Kluge, A. G. \& Farris, J. S. (1969). Quantitative phyletics and the evolution of anurans. Syst Zool 18, 1-32.

Kroppenstedt, R. M. (1982). Separation of bacterial menaquinones by HPLC using reverse phase (RP18) and a silver loaded ion exchanger as stationary phases. J Liq Chromatogr 5, 2359-2367.

Kroppenstedt, R. M. (1985). Fatty acid and menaquinone analysis of actinomycetes and related organisms. In Chemical Methods in Bacterial Systematics (Society for Applied Bacteriology Technical Series vol. 20), pp. 173-199. Edited by M. Goodfellow \& D. E. Minnikin. New York: Academic Press.

Kroppenstedt, R. M. \& Evtushenko, L. I. (2006). The family Nocardiopsaceae. In The Prokaryotes: a Handbook on the Biology of Bacteria, 3rd edn, vol. 3, pp. 754-795. Edited by M. Dworkin, S. Falkow, E. Rosenberg, K. H. Schleifer \& E. Stackebrandt. New York: Springer.

Li, M.-G., Li, W.-J., Xu, P., Cui, X.-L., Xu, L.-H. \& Jiang, C.-L. (2003). Nocardiopsis xinjiangensis sp. nov., a halophilic actinomycete isolated from a saline soil sample in China. Int J Syst Evol Microbiol 53, 317-321.

Li, W.-J., Tang, S.-K., Park, D. J., Wang, D., Lee, J. C., Xu, L.-H., Kim, C.-J. \& Jiang, C.-L. (2004). Nocardiopsis salina sp. nov., a novel halophilic actinomycete isolated from saline soil in China. Int J Syst Evol Microbiol 54, 1805-1809.

Li, W.-J., Kroppenstedt, R. M., Wang, D., Tang, S.-K., Lee, J.-C., Park, D.-J., Kim, C.-J., Xu, L.-H. \& Jiang, C.-L. (2006). Five novel species of the genus Nocardiopsis isolated from hypersaline soils and emended description of Nocardiopsis salina Li et al. 2004. Int J Syst Evol Microbiol 56, 1089-1096.

Mesbah, M., Premachandran, U. \& Whitman, W. B. (1989). Precise measurement of the $\mathrm{G}+\mathrm{C}$ content of deoxyribonucleic acid by high-performance liquid chromatography. Int J Syst Bacteriol 39, 159-167.

Meyer, J. (1976). Nocardiopsis, a new genus of the order Actinomycetales. Int J Syst Bacteriol 26, 487-493. 
Meyer, J. (1994). The genus Nocardiopsis Meyer 1976. In Bergey's Manual of Determinative Bacteriology, 9th edn, pp. 2562-2568. Edited by J. G. Holt, N. R. Krieg, P. H. A. Sneath, J. T. Staley \& S. T. Williams. Baltimore: Williams \& Wilkins.

Minnikin, D. E., O'Donnell, A. G., Goodfellow, M., Alderson, G., Athalye, M., Schaal, A. \& Parlett, J. H. (1984). An integrated procedure for the extraction of bacterial isoprenoid quinones and polar lipids. J Microbiol Methods 2, 233-241.

Peltola, J. S. P., Andersson, M. A., Kämpfer, P., Auling, G., Kroppenstedt, R. M., Busse, H.-J., Salkinoja-Salonen, M. S. \& Rainey, F. A. (2001). Isolation of toxigenic Nocardiopsis strains from indoor environments and description of two new Nocardiopsis species, N. exhalans sp. nov. and N. umidischolae sp. nov. Appl Environ Microbiol 67, 4293-4304.

Sabry, S. A., Ghanem, N. B., Abu-Ella, G. A., Schumann, P., Stackebrandt, E. \& Kroppenstedt, R. M. (2004). Nocardiopsis aegyptia sp. nov., isolated from marine sediment. Int J Syst Evol Microbiol 54, 453-456.

Saitou, N. \& Nei, M. (1987). The neighbor-joining method: a new method for reconstructing phylogenetic trees. Mol Biol Evol 4, 406-425.

Sasser, M. (1990). Identification of bacteria by gas chromatography of cellular fatty acids, MIDI Technical Note 101. Newark, DE: MIDI Inc.

Schippers, A., Bosecker, K., Willscher, S., Spröer, C., Schumann, P. \& Kroppenstedt, R. M. (2002). Nocardiopsis metallicus sp. nov., a metal-leaching actinomycete isolated from an alkaline slag dump. Int J Syst Evol Microbiol 52, 2291-2295.

Shirling, E. B. \& Gottlieb, D. (1966). Methods for characterization of Streptomyces species. Int J Syst Bacteriol 16, 313-340.

Stackebrandt, E. \& Ebers, J. (2006). Taxonomic parameters revisited: tarnished gold standards. Microbiol Today 33, 152-155.

Staneck, J. L. \& Roberts, G. D. (1974). Simplified approach to identification of aerobic actinomycetes by thin-layer chromatography. Appl Microbiol 28, 226-231.
Tamura, K., Dudley, J., Nei, M. \& Kumar, S. (2007). MEGA4: molecular evolutionary genetic analysis (MEGA) software version 4.0. Mol Biol Evol 24, 1596-1599.

Thompson, J. D., Gibson, T. J., Plewniak, F., Jeanmougin, F. \& Higgins, D. G. (1997). The CLUSTAL_X windows interface: flexible strategies for multiple sequence alignment aided by quality analysis tools. Nucleic Acids Res 25, 4876-4882.

Wayne, L. G., Brenner, D. J., Colwell, R. R., Grimont, P. A. D., Kandler, O., Krichevsky, M. I., Moore, L. H., Moore, W. E. C., Murray, R. G. E. \& other authors (1987). International Committee on Systematic Bacteriology. Report of the ad hoc committee on reconciliation of approaches to bacterial systematics. Int J Syst Bacteriol 37, 463-464.

Xiao, H., Chen, Y., Liu, Z., Huang, K., Li, W., Cui, X., Zhang, L. \& Yi, L. (2009). Phylogenetic diversity of cultivable bacteria associated with a sea anemone from coast of the Naozhou Island in Zhanjiang, China. Wei Sheng Wu Xue Bao 49, 246-250 (in Chinese).

Yang, R., Zhang, L.-P., Guo, L.-G., Shi, N., Lu, Z. \& Zhang, X. (2008). Nocardiopsis valliformis sp. nov., an alkaliphilic actinomycete isolated from alkali lake soil in China. Int J Syst Evol Microbiol 58, 1542-1546.

Yassin, A. F., Galinski, E. A., Wohlfarth, A., Jahnke, K.-D., Schaal, K. P. \& Trüper, H. G. (1993). A new actinomycete species, Nocardiopsis lucentensis sp. nov. Int J Syst Bacteriol 43, 266-271.

Yassin, A. F., Rainey, F. A., Burghardt, J., Gierth, D., Ungerechts, J., Lux, I., Seifert, P., Bal, C. \& Schaal, K. P. (1997). Description of Nocardiopsis synnemataformans sp. nov., elevation of Nocardiopsis alba subsp. prasina to Nocardiopsis prasina comb. nov., and designation of Nocardiopsis antarctica and Nocardiopsis alborubida as later subjective synonyms of Nocardiopsis dassonvillei. Int J Syst Bacteriol 47, 983-988.

Zhang, X., Zhang, L.-P., Yang, R., Shi, N., Lu, Z., Chen, W. X., Jiang, C.-L. \& Xu, L.-H. (2008). Nocardiopsis ganjiahuensis sp. nov., isolated from a soil from Ganjiahu, China. Int J Syst Evol Microbiol 58, 195199. 